Tersedia online di: http://ejournal-balitbang.kkp.go.id/index.php/bawal
e-mail:bawal.puslitbangkan@gmail.com
BAWAL wIDYA RISET PERIKANAN TANGKAP
Volume 10 Nomor 2 Agustus 2018
p-ISSN: 1907-8226
e-ISSN: 2502-6410
BAWAL
Nomor Akreditasi Kementerian RISTEKDIKTI: 21/E/KPT/2018

\title{
ANALISIS PERTUMBUHAN DAN LAJU EKSPLOITASI IKAN TONGKOL ABU-ABU, Thunnus tonggol (Bleeker, 1851) DI PERAIRAN LAUT JAWA
}

\section{GROWTH ANALYSIS AND EXPLOITATION RATE OF LONGTAIL TUNA, Thunnus tonggol (Bleeker, 1851) IN JAVA SEA WATERS}

\author{
Yoke Hany Restiangsih* ${ }^{1}$ dan Thomas Hidayat ${ }^{1}$ \\ 'Balai Riset Perikanan Laut, Kompl Raiser Jalan Raya Bogor Km 47 Nanggewer Mekar, Cibinong, Bogor \\ Teregistrasi I tanggal: 03 Mei 2017; Diterima setelah perbaikan tanggal: 05 Juni 2018; \\ Disetujui terbit tanggal: 06 Juni 2018
}

\begin{abstract}
ABSTRAK
Tongkol abu-abu atau longtail tuna (Thunnus tonggol) salah satu jenis ikan tuna neritik sebagai target penangkapan armada pukat cincin, jaring isang, dan pancing di Laut Jawa. Penelitian ini bertujuan untuk mengetahui parameter pertumbuhan, umur dan mortalitas ikan tongkol abu-abu untuk penyusunan strategi pengelolaannya. Pengumpulan data frekuensi panjang dan bobot ikan dilakukan di Pelabuhan Perikanan Nusantara (PPN) Pekalongan pada Januari - Nopember 2014. Hasil penelitian menunjukkan hubungan panjang-bobot ikan tongkol abu-abu bersifat isometrik dan indek kecepatan pertumbuhan 3,46/tahun. Ikan dapat tumbuh hingga mencapai panjang asimtotik $\left(\mathrm{L}_{\infty}\right)=85 \mathrm{~cm}$ dengan laju pertumbuhan $(\mathrm{K})$ sebesar $0,4 /$ tahun. Umur teoritis pada saat panjang ikan sama dengan nol $\left(\mathrm{t}_{0}\right)$ adalah 0,046 tahun. Umur maksimal diduga 15 tahun. Mortalitas alami (M) sebesar 0,61/tahun, mortalitas karena penangkapan (F) 1,01/tahun, mortalitas total (Z) 1,62/tahun. Tingkat eksploitasi (E) sebesar 0,59 berarti bahwa pemanfaatan ikan tongkol abu-abu di Laut Jawa cenderung sudah penuh (fully exploited).
\end{abstract}

Kata Kunci: Tongkol abu-abu; pertumbuhan; eksploitasi; Laut Jawa

\section{ABSTRACT}

Longtail tuna as one of neritic tuna species are commonly caught by purse seine, gill net and hand line in java sea.. This research activity aims to determine population parameters i.e. growth, mortality and its exploitation rate that can contribute to strengthen database on preparation its harvest strategy. The Collecting of length and weight data were conducted at Pekalongan fishing port during period of January to November 2014. The Longweigth relationship was isometric and growth performance index was 3.46/year. The asymptotic length rate $\left(L_{\infty}\right)$ was $85 \mathrm{cmFL}$, growth rate $(K)$ was $0.4 /$ year and zero age $\left(t_{0}\right)$ was 0.046 year. This length is reached allegedly at the 15 years age. Natural mortality $(M)$ was 0.6/year, fishing mortality $(F)$ was 1.01/year, total mortality $(Z)$ was 1.62/yera. The exploitation rate $(E)$ was 0.59 , it means exploitation of longtail tuna in the Java Sea tend to highly exploited.

Keywords: Longtail tuna; growth rate; exploitation rate; Java sea

\section{PENDAHULUAN}

Ikan tongkol abu-abu atau longtail tuna (Thunnus tonggol) merupakan salah satu jenis ikan pelagis yang bersifat oseanodromous dan populasinya terutama berada di perairan neritik yang jernih (Carpenter \& Niem, 2001). Ikan ini tersebar di seluruh wilayah Indo-Pasifik Barat (antara $47^{\circ} \mathrm{LU}$ dan $33^{\circ} \mathrm{S}$ ) mulai dari utara Australia, Papua Nugini dan Indonesia sedangkan dari barat laut melalui
Malaysia dan Thailand, terus tersebar hingga ke timur laut dan selatan Jepang, barat laut Iran hingga Laut Merah (Collette \& Nauen, 1983; Froese \& Pauly, 2010).Tongkol abu-abu adalah spesies terkecil kedua dari delapan spesies Thunnus, tumbuh dengan ukuran maksimal $142 \mathrm{~cm}$ dan bobot $35,9 \mathrm{~kg}$ (Griffiths et al., 2009). Jenis ini umumnya menjadi target penangkapan pada perikanan pukat cincin, jaring insang dan pancing, meliputi mackerel tuna (Euthynnus affinis) dan frigate tuna (Auxis thazard dan Auxis rochei) (Yesaki, 1994). 
Laut Jawa merupakan bagian dari paparan Sunda dimana seluruhnya merupakan perairan territorial dengan kedalaman maksimal 70 meter, kegiatan penangkapan sebagian besar dilakukan di pantai utara Jawa (Nurhakim et al., 2007). Pada tahun 2014 produksi perikanan tangkap di Laut Jawa terbesar diseluruh Indonesia yaitu $(17,91 \%$ dari total produksi Indonesia) 6.037.654 ton. Produksi ikan tongkol abu-abu di Indonesia dari tahun 2005 hingga 2014 mengalami penurunan, pada tahun 2005 produksi 121.792 ton/tahun meningkat di tahun 2007 mencapai 145.587 ton/ tahun, mengalami penurunan hingga tahun 2014 menjadi 55.589 ton/tahun. Produksi ikan tongkol abu-abu di Laut Jawa tahun 2014 sebesar 5.362 ton atau 9,6\% dari total produksi nasional, $0,5 \%$ dari total produksi Laut Jawa, dan 2,5\% dari total produksi ikan pelagis besar di Laut Jawa (Anonimus, 2015). Penurunan produksi tongkol abuabu juga terjadi di Oman (Al-Siyabi et al., 2014) dimana hasil tangkapan menurun dari 2,2 kg/hari (2002) menjadi 0,5/hari (2013). Penurunan produksi di Indonesia dan Oman berlawanan dengan kenaikan produksi ikan tuna neritik di Selat Malaka bagian Malaysia (Basir \& Bakar, 2011).

Upaya penangkapan yang terus meningkat dan penurunan produksi secara terus menerus menjadi ancaman dalam keberlanjutan populasi tongkol abu-abu di Indonesia. Dalam rangka penentuan opsi pengelolaan yang baik diperlukan informasi dasar terkait dengan parameter populasi ikan tongkol abu-abu di suatu wilayah. Penelitian ini bertujuan untuk mengetahui parameter pertumbuhan, umur dan mortalitas ikan tongkol abu-abu. Hasil penelitian ini diharapkan dapat digunakan sebagai bahan masukan untuk pengelolaan ikan tongkol abu-abu di Laut Jawa.

\section{Waktu dan Lokasi}

Pengumpulan contoh ikan tongkol abu-abu (Thunnus tonggol) dilakukan di Pelabuhan Perikanan Nusantara (PPN) Pekalongan pada bulan Januari sampai November 2014. Pengukuran panjang cagak (fork-length, FL) dan bobot individu dilakukan setiap bulan hasil tangkapan pukat cincin mini dan jaring insang dengan bantuan tenaga enumerator. Pengambilan contoh dilakukan secara acak setiap hari dengan target 400-900 ekor setiap bulannya.

\section{Analisis Data}

\section{Hubungan Panjang-Bobot}

Hubungan panjang-bobot mengikuti hukum kubik, bahwa bobot ikan sebagai pangkat tiga dari panjangnya sesuai dengan persamaan dari Bal \& Rao (1984), yaitu:

$W=a L^{b}$

$\log \mathrm{W}=\log \mathrm{a}+\mathrm{b} \log \mathrm{L}$ dimana;

$\mathrm{W}=$ bobot individu (gram)

$\mathrm{L}=$ panjang cagak $(\mathrm{cm})$

$\mathrm{a}=$ intercept (perpotongan antara garis regresi dengan sumbu y)

$\mathrm{b}=$ koefisien regresi (sudut kemiringan garis)

Untuk mengetahui sifat pertumbuhan, maka dilakukan uji-t terhadap nilai b berdasarkan kriteria Bal \& Rao (1984):

a) Jika $\mathrm{b}=3$, pertumbuhan bersifat isometrik, yaitu pertambahan panjang sama dengan pertumbuhan bobotnya,

b) Jika b>3, maka pola pertumbuhan bersifat allometrik positif, yaitu pertambahan bobot lebih cepat dari pertambahan panjangnya,

c) Jika b $<3$, maka pola pertumbuhan bersifat allometrik negatif, yaitu pertambahan panjang lebih cepat dari pertambahan bobotnya.

Untuk mengetahui apakah nilai b yang diperoleh lebih besar, sama atau lebih kecil dari 3 dilakukan uji-t pada selang kepercayaan 95\% (Steel \& Torrie, 1993):

$t_{\text {hitung }}=\left|\frac{3-b}{S b}\right|$

$\mathrm{H}_{0}: \mathrm{b}=3$ (isometrik)

$\mathrm{H}_{1}: \quad \mathrm{b} \neq 3$ (alometrik)

- Jika $\mathrm{t}_{\text {hitung }}$ lebih kecil dari $\mathrm{t}_{\text {tabel }}$ maka $\mathrm{H}_{0}$ diterima dan $\mathrm{H}_{1}$ ditolak.

- Jika $\mathrm{t}_{\text {hitung }}$ lebih besar dari $\mathrm{t}_{\text {tabel }}$ maka $\mathrm{H}_{1}$ diterima dan $\mathrm{H}_{0}$ ditolak.

Untuk memperoleh nilai sb (simpangan baku) dipergunakan persamaan berikut :

$$
\begin{aligned}
& \sum \mathrm{d}^{2} \mathrm{yx}=\sum \mathrm{y}^{2}-\frac{\left(\sum \mathrm{xy}\right)^{2}}{\sum \mathrm{x}^{2}} . \\
& S^{2} y x=\frac{\sum d^{2} y x}{n-2} \\
& S b^{2}=\frac{S^{2} y x}{\sum x^{2}} \\
& S b=\sqrt{S b^{2}}
\end{aligned}
$$

Nilai $\mathrm{t}_{\text {tabel }}$ dalam taraf nyata $5 \%(\mathrm{n}-2)$.

\section{Estimasi Parameter Pertumbuhan}

Pendugaan nilai koefesien pertumbuhan $\mathrm{L}_{\infty}$ dan $\mathrm{K}$ dilakukan dengan bantuan program ELEFAN I dengan menggunakan data frekuensi bulanan yang berasal dari 2 
set data yang berasal dari hasil sampling pada pukat cincin mini dan jaring insang. Masing-masing set data tersebut juga digunakan dalam identifikasi kelompok umur (cohort) yang muncul, serta penentuan starting point (SP) dan starting length (SL) yang akan diterapkan dalam analisis dengan ELEFAN I. Identifikasi dugaan kelompok umur yang muncul didasarkan pada kelompok-kelompok ukuran/ umur (komponen kohor) yang diperoleh berdasarkan metode Bhattacharya (Spare \& Venema, 1999 dalam Suwarso, 2002). Nilai dugaan umur teoritis pada saat panjang ikan sama dengan nol $\left(\mathrm{t}_{0}\right)$ diperoleh melalui persamaan Pauly (1980) dengan menggunakan persamaan:

$\log -\left(\mathrm{t}_{0}\right)=-0,3922-0,2752 \log \mathrm{L}-1,038 \log \mathrm{K}$

Ketiga nilai parameter pertumbuhan tersebut digunakan sebagai masukan dalam membuat model pertumbuhan Von Bertalanffy. menggunakan persamaan sebagai berikut (Sparre \& Venema, 1999) :

$\mathrm{L}_{\mathrm{t}}=\mathrm{L}_{\infty}\left(1-\mathrm{e}^{-\mathrm{k}(\mathrm{t}-\mathrm{to})}\right)$

Dimana;

$\mathrm{L}_{\mathrm{t}}$ : ukuran panjang ikan pada saat umur $\mathrm{t}$ tahun $(\mathrm{cm})$

$\mathrm{L}_{\infty}$ : panjang maksimum ikan yang dapat dicapai

$\mathrm{t}_{0}$ : umur ikan teoritis pada saat panjangnya $0 \mathrm{~cm}$

$\mathrm{K}$ : Koefisien pertumbuhan

Untuk membandingkan pertumbuhan dan umur dari penelitian yang lain serta kecepatan pertumbuhan maka digunakan Growth Performance Index (Ø.) atau sering disebut phi-prime (Pauly \& Munro, 1984), yaitu:

$\varnothing .=\log (\mathrm{K})+2 \log \left(\mathrm{L}_{\infty}\right)$

\section{Estimasi Parameter Kematian}

Tingkat kematian total (Z) dalam suatu perikanan penting diketahui untuk menganalisis dinamika populasi atau stok ikan. Kematian dapat dibedakan menjadi kematian alami (M) dan kematian karena penangkapan (F). Kematian total dapat diduga dari pergeseran kelimpahan kelompok umur dan dari analisis kurva hasil tangkapan menggunakan data frekuensi panjang (Sparre \& Venema, 1999). Kematian total dihitung menggunakan rumus:

$\mathrm{Z}=\mathrm{M}+\mathrm{F}$

Kematian alami (M) diduga dengan metode persamaan empiris Pauly (1980) :

$\log \mathrm{M}=-0,0152-0,279 * \log \mathrm{L}_{\infty}+0,6543 * \log \mathrm{K}+$ $0,4634 * \log \mathrm{T}$

dimana:

M : mortalitas alami

$\mathrm{K}$ : koefisien pertumbuhan

$\mathrm{L}_{\infty}$ : panjang maksimum

$\mathrm{T}$ : suhu rata-rata tahunan $\left({ }^{\circ} \mathrm{C}\right)$

\section{HASIL DAN BAHASAN Hasil}

\section{Hubungan Panjang-Bobot}

Hasil analisis hubungan panjang-bobot ikan tongkol abu-abu menunjukkan persamaan $\mathrm{W}=0,015 \mathrm{~L}^{3,021}$ dengan nilai korelasi $\left(r^{2}\right)$ sebesar 0,99\% (Gambar 1). Setelah dilakukan uji-t dengan tingkat kepercayaan $95 \%(a ́=0,05)$ didapatkan pola pertumbuhan bersifat isometrik yang berarti pertambahan panjang sama cepatnya dengan pertambahan bobotnya.

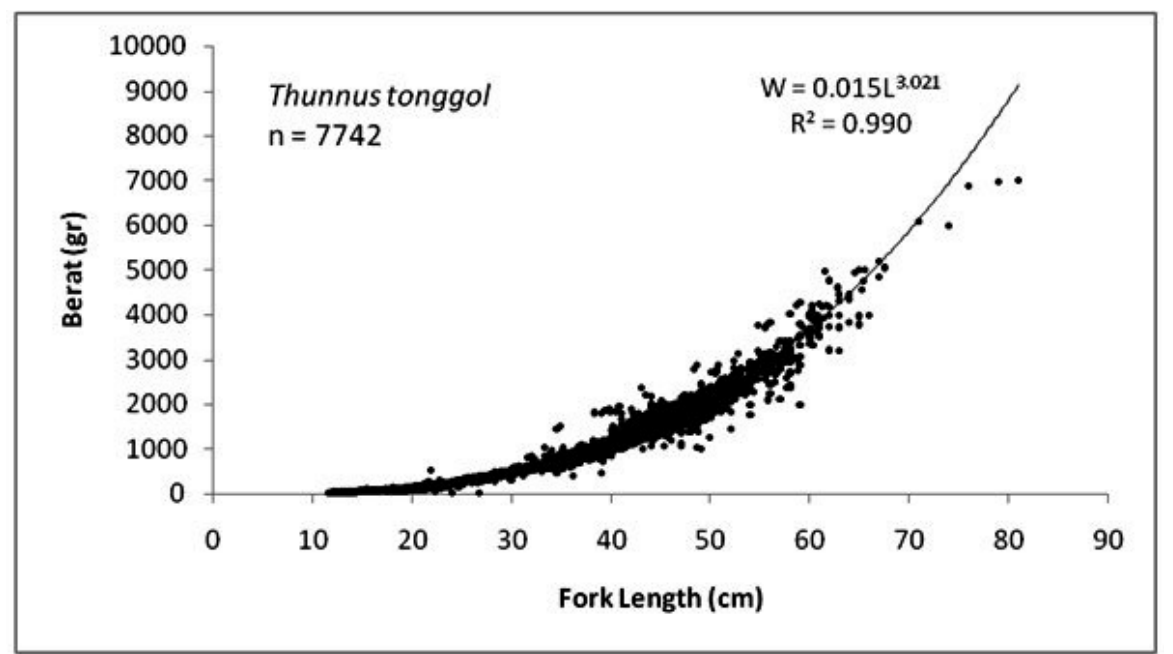

Gambar 1. Hubungan antara panjang cagak dan bobot ikan tongkol abu-abu di Laut Jawa.

Figure 1. Length-weight relationship of longtail tuna in Java Sea. 


\section{Struktur Ukuran Panjang}

Total hasil pengukuran panjang cagak (fork length) diperoleh sejumlah 7.742 terdiri dari 4.043 ekor hasil tangkapan jaring insang dengan kisaran panjang $18-81$
cmFL modus pada kelas panjang 47 - $49 \mathrm{cmFL}$ dan 3.699 hasil tangkapan pukat cincin mini dengan kisaran panjang $11,5-74 \mathrm{cmFL}$ (modus pada kelas panjang $45-47 \mathrm{cmFL}$ ). Distribusi ukuran panjang masing-masing alat tangkap dapat dilihat pada Gambar 2.

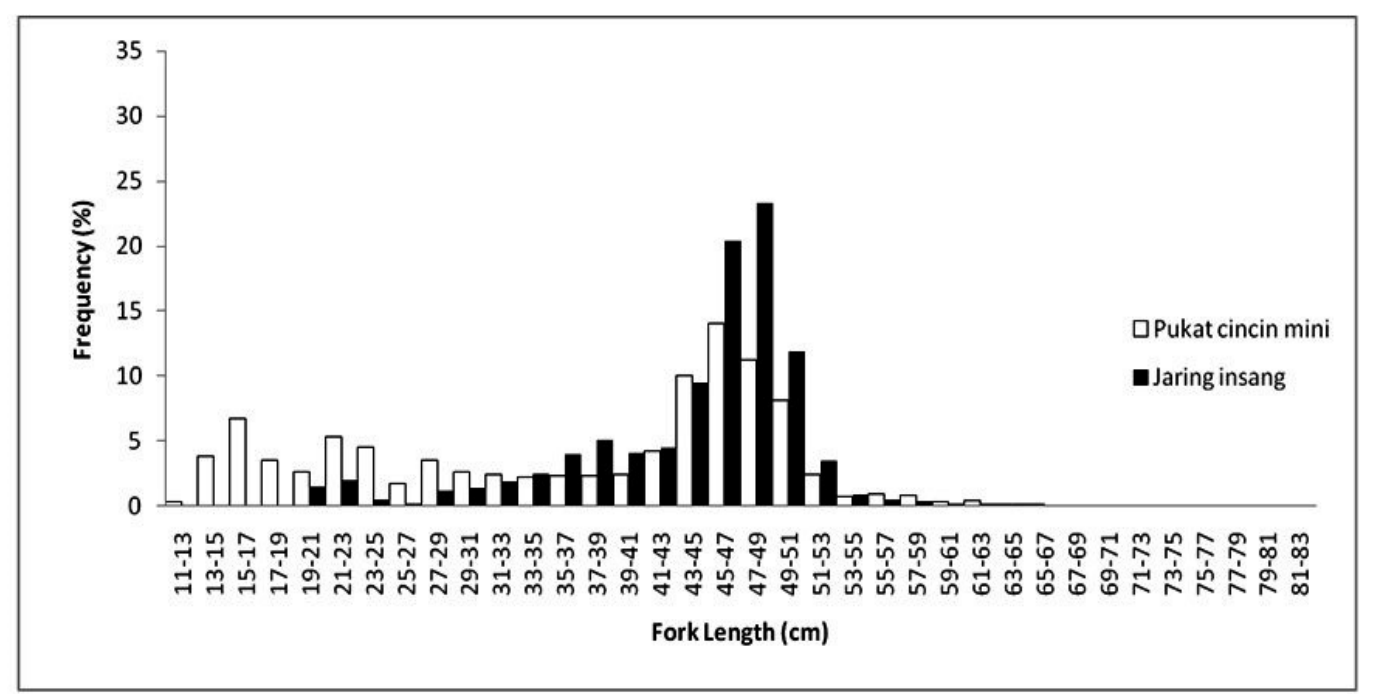

Gambar 2. Distribusi panjang cagak ikan tongkol abu-abu yang tertangkap jaring insang dan pukat cincin mini di perairan Laut Jawa.

Figure 2. Fork length distribution of llongtail tuna caught by gillnet and mini purse seine in Java Sea.

\section{Estimasi Parameter Pertumbuhan}

Distribusi ukuran panjang bulanan tongkol abu-abu yang tertangkap pukat cincin mini dan jaring insang terlihat pada Gambar 3. Secara umum terlihat bentuk-bentuk poligon yang tersebar normal (seringkali polymodal) walaupun dalam beberapa bulan pergeseran modusnya (modal progression) kurang nyata, terutama pada sampel yang berasal dari jaring insang. Pada jaring insang terlihat kelompok ukuran yang relatif lebih besar. Kelompok ikanikan muda (berukuran kecil) tampak pada contoh ikan yang berasal dari pukat cincin mini Bulan April - Juli diduga merupakan ukuran rekruit tongkol abu-abu sebagai major kohor. Sementara tak terlihat adanya indikasi kohor minor. Hasil pemisahan kelompok ukuran pada masing-masing data sebaran frekuensi panjang dengan metode Bhattacharya ditunjukkan pada Gambar 3.

Gambar 4 menampilkan panjang rata-rata dari tiap kelompok umur (komponen kohor) yang teridentifikasi setiap bulan, baik pada alat tangkap pukat cincin mini maupun jaring insang. Garis pertumbuhan (growth line) diasumsikan sebagai pertumbuhan ikan tongkol abu-abu akan melalui titik-titik yang teridentifikasi tersebut (ukuran rata-rata/mean atau komponen kohor), seperti terlihat pada gambar.

Analisis pertumbuhan dengan program ELEFAN I menerapkan nilai SP (starting point) dan SL (starting length) yang dimaksud yaitu titik dimulainya tracking grwoth line suatu nilai panjang, misal SP 1 (Januari) dengan SL 20,7 cm. Diperoleh koefesien pertumbuhan (K) sebesar $0,4 /$ tahun dan nilai panjang asimtotik $\left(\mathrm{L}_{\infty}\right)$ sebesar $85 \mathrm{~cm}$. Dugaan umur teoritis pada saat panjang ikan sama dengan nol $\left(\mathrm{t}_{0}\right)$ adalah 0,04/tahun. Dengan demikian diperoleh persamaan pertumbuhan ikan tongkol abu-abu adalah Lt $=85\left(1-\mathrm{e}^{-0,4(\mathrm{t}-0.046)}\right)$. Dari persamaan tersebut dapat dibuat kurva hubungan antara umur dengan panjang ikan (Gambar 5). Ukuran panjang (FL) ikan tongkol abu-abu terkecil selama penelitian tercatat $11,5 \mathrm{~cm}$ diduga berumur 0,34 tahun (sekitar 4 bulan) tertangkap dengan alat tangkap pukat cincin mini, ukuran terpanjang tercatat $81 \mathrm{~cm}$ diduga mencapai 15 tahun dengan alat tangkap jaring insang. Indek Kecepatan Pertumbuhan ( $\left.\varnothing^{\prime}\right)$ ikan tongkol abu-abu di perairan Laut Jawa diperoleh sekitar 3,46. 


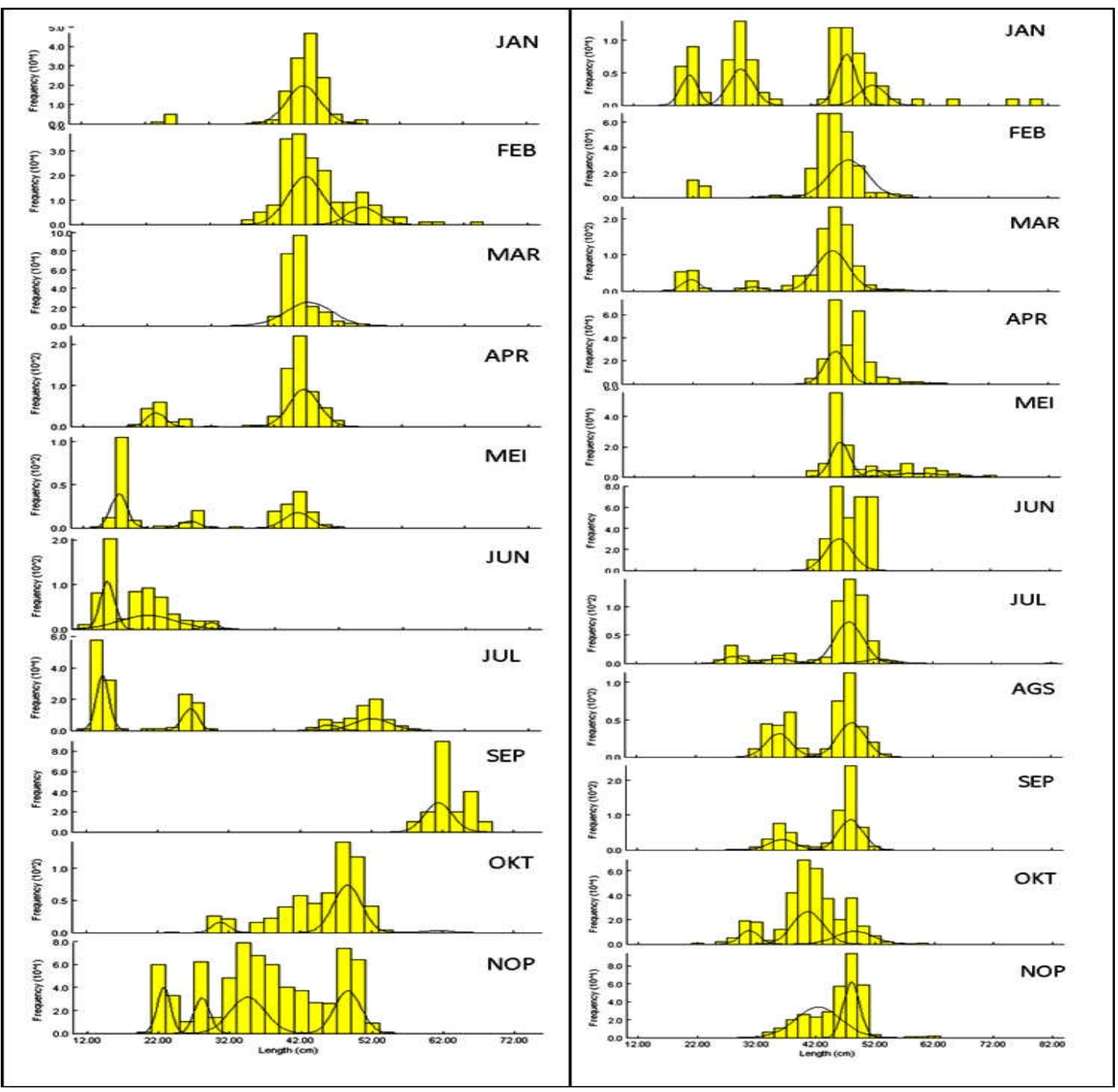

(a)

(b)

Gambar 3. Distribusi panjang (FL) ikan tongkol abu-abu yang tertangkap a). Pukat cincin mini dan b). Jaring insang di perairan Laut Jawa.

Figure 3. Length distribution(FL) of longtail tuna caught by gillnet and mini purseseine in Java Sea.

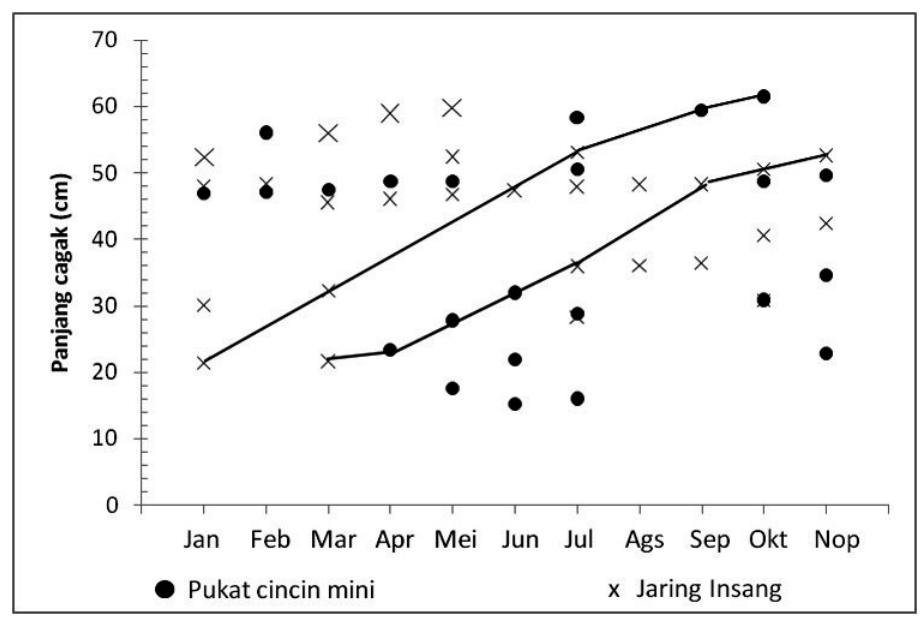

Gambar 4. Diagram pencar garis pertumbuhan ikan tongkol abu-abu di perairan Laut Jawa.

Figure 4. Scatter diagrams of the growth line of longtail tuna in Java Sea. 


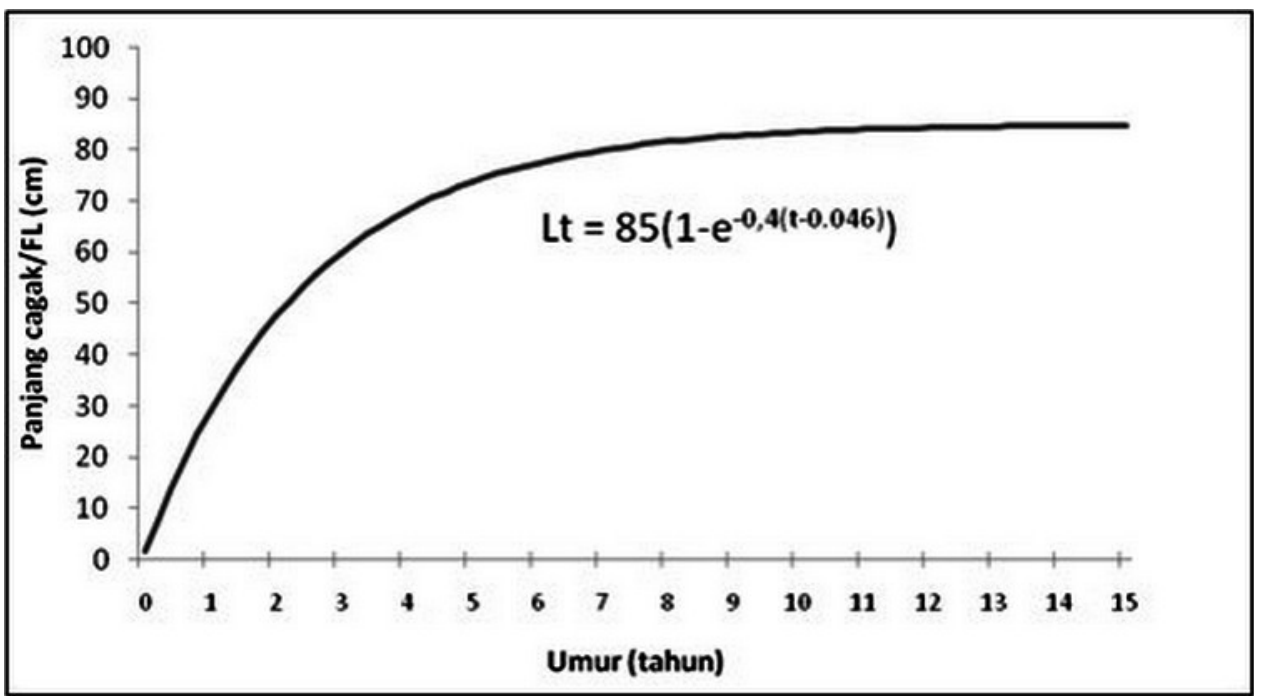

Gambar 5. Kurva pertumbuhan ikan tongkol abu-abu di Laut Jawa.

Figure 5. Growth curve of longtail tuna in Java Sea.

\section{Estimasi Parameter Kematian}

Dengan menggunakan rumus empiris Pauly (1980) dan suhu rata-rata perairan di lokasi penelitian $29^{\circ} \mathrm{C}$, maka diperoleh laju mortalitas alami (M) sebesar 0,76/tahun. Untuk ikan peruaya cepat seperti halnya tongkol, maka dikoreksi menggunakan konstanta sebesar 0,8 dengan demikian laju mortalitas alami menjadi 0,61/tahun. Laju kematian total (Z) sebagai slope diestimasi dari kurva konversi panjang terhadap hasil tangkapan (length converted catch curve) yang dihitung dengan memasukkan parameter $\mathrm{K}, \mathrm{L}_{\infty}$, dan $\mathrm{t}_{0}$. Analisis regresi antara umur relatif dan panjang cagak ditampilkan pada Gambar 6. Diperoleh nilai Z sebagai slope sebesar 1,62/ tahun. Mortalitas penangkapan (F) yang dihitung dari selisih antara nilai $\mathrm{Z}$ dan $\mathrm{M}$ diperoleh sebsar 1,1/tahun. Dari hasil ini dapat dihitung tingkat pemanfaatan (E) ikan tongkol abu-abu di perairan Laut Jawa diduga sebesar 0,59.

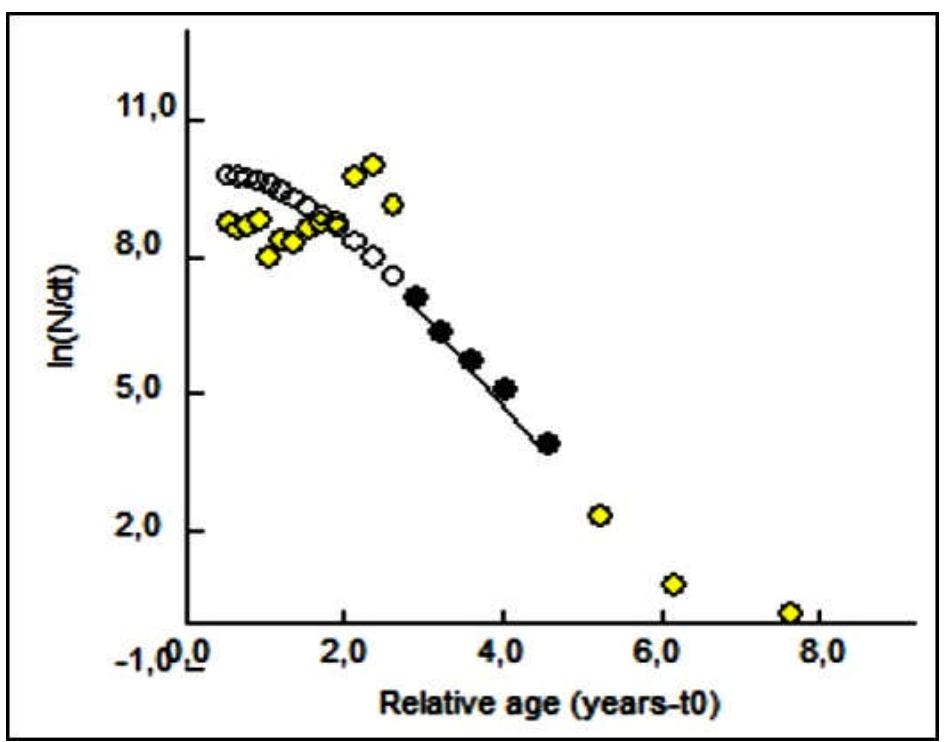

Gambar 6. Kurva hasil tangkapan menurut ukuran panjang tongkol abu-abu di Laut Jawa.

Figure 6. Length converted catch curve of longtail tuna in Java Sea.

\section{Bahasan}

Analisis hubungan panjang-bobot ikan tongkol abuabu di Laut Jawa dihasilkan persamaan $\mathrm{W}=0,015 \mathrm{~L}^{3,021}\left(\mathrm{r}^{2}\right.$ $=0,99)$ dengan nilai $b=3,021$. Setelah dilakukan uji t dengan tingkat kepercayaan $95 \%$, diperoleh nilai $\mathrm{t}_{\text {hitung }}=0,215$ lebih kecil dari $t_{\text {tabel }}=1,965$. Hal ini dapat disimpulkan bahwa pola pertumbuhan bersifat isometrik dengan nilai $b=3$, menunjukkan pertumbuhan bobot seiring dengan pertambahan panjangnya. Hasil ini sama dengan penelitian Abdussamad et al. (2012) di perairan India. Sebagai pembanding dikemukakan hasil dari berbagai 
lokasi penelitian (Tabel 1). Menurut Biswas, (1993) dalam Kaymaram \& Darvishi, (2012) perbedaan nilai a dan b ini tergantung pada jenis kelamin, tahap kedewasaan, intensitas makan, dan lainnya. Selanjutnya menurut Gulland
(1983); Sparre \& Venema (1999), variasi nilai b ini juga disebabkan berbagai faktor seperti suhu, salinitas, makanan (kuantitas, kualitas dan ukuran), jenis kelamin, tahap kematangan gonad dan kelestarian habitat.

Tabel 1. Parameter a dan b pada hubungan panjang dan bobot beberapa penelitian tongkol abu-abu di beberapa perairan dunia

Table 1. The parameters $a \& b$ in length-weight relationship oflongtail tuna many waters in the world

\begin{tabular}{|c|c|c|c|c|}
\hline Referensi (Reference) & $\begin{array}{c}\text { Lokasi } \\
\text { penelitian } \\
\text { (Study area) }\end{array}$ & $\begin{array}{l}\text { Parameter Panjang } \\
\text { (Length parameter) }\end{array}$ & $\mathbf{a}$ & b \\
\hline James et al. (1993) & India & TL & 0,000083 & 2,71 \\
\hline Khorshidian \& carrara (1993) & Iran & FL & 0,0015 & 2,43 \\
\hline Griffiths et al. (2010) & Australia & FL & 0,00005 & 2,83 \\
\hline Darvishi et al. (2003) & Iran & FL & 0,00004 & 2,7 \\
\hline Kaymaram et al. (2011) & Persian Gulf & FL & 0,00002 & 2,83 \\
\hline Abdussamad et al. (2012) & India & FL & 0,0148 & 3 \\
\hline Wagiyo \& Febrianti (2015) & Perairan Langsa & FL & 0,0495 & 2,71 \\
\hline Penelitian ini & Laut Jawa & FL & 0,015 & 3,02 \\
\hline
\end{tabular}

\section{Keterangan / remarks :}

TL : panjang total / total length

FL : panjang cagak / fork length

Hasil tangkapan ikan tongkol abu-abu dari jaring insang di Laut Jawa diperoleh panjang maksimum $81 \mathrm{cmFL}$. Hasil tersebut lebih besar dari tangkapan jaring insang di perairan Langsa yaitu $51 \mathrm{cmFL}$ (Wagiyo \& Febrianti, 2015), perairan Taiwan yaitu 79,6 cmFL (Chiang et al., 2011), perairan Jepang yaitu $72 \mathrm{cmFL}$ (Itoh et al., 1996) dan ukuran tersebut lebih kecil jika dibandingkan dengan ikan Teluk Persia yaitu $125 \mathrm{cmFL}$ (Kaymaram et al., 2011). Diperoleh ukuran terkecil hasil tangkapan dengan pukat cincin mini sebesar 11,5 cmFL. Nilai ini lebih kecil dibandingkan dengan ikan yang tertangkap diperairan Langsa sebesar $29 \mathrm{cmFL}$ (Wagiyo \& Febrianti, 2015), Australia sebesar 23,8 cmFL (Griffith et al., 2010), Samudera Hindia sebesar $15 \mathrm{cmFL}$ (Sharma et al., 2012) dan diperairan Selatan India sebesar $23 \mathrm{cmFL}$ (Abdussamad et al., 2012). Menurut Griffith et al. (2010), ikan tongkol abu-abu di perairan tropis umumnya memiliki panjang maksimal lebih kecil dibandingkan dengan ikan di perairan subtropis. Selanjutnya disebutkan bahwa perbedaan alat tangkap serta lokasi penangkapan mempengaruhi sebaran ukuran ikan yang tertangkap.

Berdasarkan diagram pencar struktur ukuran panjang ikan sebagaimana pada Gambar 4 diperoleh dua garis pertumbuhan (growth line) yang diduga pertumbuhan ikan tongkol memiliki dua alternatif atau pilihan pertumbuhan dengan melalui titik-titik pada masingmasing garis tersebut. Kelompok umur terkecil yang merupakan awal rekrutmen diduga berlangsung antara bulan Mei-Agustus.

Nikolskii (1969) menyatakan parameter pertumbuhan merupakan faktor penting dalam mempelajari dinamika populasi ikan, yaitu digunakan untuk menduga kondisi dan status sumberdaya ikan di suatu perairan seperti besarnya sediaan, tingkat pengusahaan serta kemungkinan pengelolaannya.

Dugaan panjang asimtotik $\left(\mathrm{L}_{\infty}\right)$ ikan tongkol abu-abu di Laut Jawa sebesar $85 \mathrm{cmFL}$ tercapai pada umur lebih dari 15 tahun. Nilai indek kecepatan pertumbuhan sebesar (Ø.) 3,46 menunjukkan pertumbuhan ikan tongkol abuabu tergolong cepat. Griffiths et al. (2010) menyebutkan pertumbuhan ikan tongkol abu-abu di perairan tropis umumnya mempunyai pertumbuhan yang cepat. Laju pertumbuhan $(\mathrm{K})$ pada penelitian ini sebesar 0,4 /tahun, lebih rendah dibandingkan dengan ikan tongkol abu-abu di perairan langsa sebesar 1,5/tahun (Wagiyo \& Febrianti, 2015) dan lebih tinggi dari Teluk Persia dengan nilai K sebesar 0,35/tahun (Kaymaram et al., 2011), sedangkan di perairan Australia diperoleh nilai K sebesar 0,233/tahun (Griffiths et al, 2010). Hasil analisis menunjukkan panjang asimtotik ( $\mathrm{L}$, ) sebesar $85 \mathrm{cmFL}$. Nilai tersebut lebih tinggi dibandingkan dengan ikan tongkol abu-abu di Selat Malaka (Wagiyo \& Febrianti, 2015) yaitu 55,65 cmFL dan lebih rendah dari nilai di perairan pantai Timur India yaitu 123,5 cmFL (Abdussamad et al, 2012) dan di Teluk Persia sebesar 133,79 cmFL (Kaymaram et al., 2011). Perbedaan karakteristik lingkungan, spesifikasi alat tangkap, jumlah contoh ikan, serta distribusi panjang yang diperoleh diduga menjadi faktor utama perbedaan panjang maksimum dan laju pertumbuhan. Selanjutnya menurut Pauly (1980) dalam Sparre \& Venema 1999, nilai K merupakan suatu parameter yang menentukan seberapa cepat ikan mencapai panjang asimtotiknya. Menurut Gulland (1983), apabila nilai $\mathrm{K}<1$ ikan ini mempunyai pertumbuhan lambat. Laju 
pertumbuhan yang lambat sangat mempengaruhi pola pemanfaatannya. Untuk mencapai pola pemanfaatan yang lestari, perlu dipertimbangkan waktu yang tepat untuk menangkap ikan. Ikan yang berumur muda harus dibiarkan tumbuh dewasa terlebih dahulu sebelum ditangkap. Penangkapan ikan muda yang berlebihan akan mengakibatkan kelebihan tangkap pertumbuhan (growth overfishing). Hal ini juga menyebabkan kelebihan tangkap penambahan baru (recruitment overfishing), karena ikanikan muda yang belum sempat dewasa dan bertelur sudah ditangkap. Nilai $\mathrm{L}_{\infty}, \mathrm{K}$, dan $\mathrm{t}_{\mathrm{o}}$ dari beberapa lokasi penelitian tersaji pada Tabel 2.

Tabel 2. Parameter pertumbuhan ikan tongkol abu-abu di beberapa lokasi penelitian.

Table 2. Estimation growth parameter of longtail tuna in several location.

\begin{tabular}{|c|c|c|c|c|}
\hline Referensi/Reference & Lokasi/Study area & $\mathbf{L}_{\infty}$ & $\mathbf{K}$ & $\mathbf{t}_{\mathbf{o}}$ \\
\hline Wilson (1981a) & Papua New Guinea & 122,9 & 0,41 & $-0,032$ \\
\hline Wilson (1981b) & Papua & 131,8 & 0,395 & $-0,035$ \\
\hline Silas et al. (1985) & India & 93 & 0,49 & $-0,240$ \\
\hline Supongpan \& Saikliang (1987) & Thailand & 58,2 & 1,44 & $-0,27$ \\
\hline Prabhakar \& Dudley (1989) & Omani Waters & 133,6 & 0,228 & \\
\hline Yesaki (1989) & Thailand & 108 & 0,55 & \\
\hline Itoh et al. (1999) & Japan & 55 & 1,7 & $-0,089$ \\
\hline Griffiths et al. (2010) & Australia & 135,4 & 0,233 & $-0,02$ \\
\hline Kaymaram et al. (2011) & Persian Gulf & 133,79 & 0,35 & \\
\hline Abdussamad et al. (2012) & India & 123,5 & 0,51 & $-0,0319$ \\
\hline Wagiyo \& Febrianti (2015) & Selat Malaka & 55,65 & 1,5 & \\
\hline Penelitian ini & Laut Jawa & 85 & 0,4 & $-0,046$ \\
\hline
\end{tabular}

Laju kematian karena penangkapan (F) bervariasi menurut keragaman upaya penangkapan setiap tahunnya. Nilai F menunjukkan seberapa besar dan meningkatnya tekanan penangkapan (fishing pressure) terhadap stok ikan di suatu perairan (Suman \& Boer, 2005). Nilai mortalitas alami (M) dari ikan tongkol abu-abu yaitu 0,61/tahun. Nilai ini lebih rendah dari mortalitas alami diperairan Langsa sebesar 1,04/tahun. Nilai mortalitas penangkapan (F) sebesar 1,01/tahun. Hasil ini lebih rendah jika dibandingkan dengan ikan yang tertangkap di perairan Langsa sebesar 2,07/tahun (Wagiyo \& Febrianti, 2015), Teluk Persia sebesar 1,38/tahun (Kaymaram et al., 2013) dan India Timur sebesar 2,94/tahun (Abdussamad et al., 2012). Selain karena perbedaan tekanan penangkapan, perbedaan nilai mortalitas alami dan mortalitas penangkapan dipengaruhi oleh banyaknya contoh ikan dan kisaran ukuran yang diperoleh. Widodo (1988) menyatakan perbedaan nilai parameter pertumbuhan ini lebih diperngaruhi oleh komposisi ikan contoh dan cara atau metode penangkapan yang digunakan. Jika ikan muda lebih banyak tertangkap maka koefisien pertumbuhan akan tinggi dan sebaliknya jika ikan berumur tua yang banyak tertangkap, maka koefisien pertumbuhan akan rendah.

Tingkat pemanfaatan (E) ikan tongkol abu-abu di Laut Jawa sebesar 0,59, nilai ini lebih besar dibanding diperairan Langsa sebesar 0,51 (Wagiyo \& Febrianti, 2015) dan lebih rendah dibandingkan di India Timur 0,774 (Abdussamad et al., 2012). Nilai laju eksploitasi (E) tersebut mengindikasikan bahwa tingkat pemanfaatan ikan tongkol abu-abu tersebut sudah melebihi nilai optimumnya $(\mathrm{E}=0,50)$. Pauly et al (1984) menyebutkan nilai laju eksploitasi yang rasional dan lestari di suatu perairan berada pada nilai $\mathrm{E}<0,5$ atau paling tinggi pada nilai $\mathrm{E}=$ 0,5 . Kondisi tersebut perlu kehati-hatian dalam melakukan pemanfaatan ikan tongkol di Laut Jawa yaitu dengan, tidak melakukan penambahan upaya penangkapan yang mengarah pada kondisi lebih tangkap (over fishing). Nilai laju eksploitasi ikan tongkol abu-abu di Laut Jawa yang besarnya 0,59 tidak berbeda jauh dengan hasil penelitian ikan tongkol komo oleh Chodriyah et al. (2013) sebesar $0,57 /$ tahun. Hal tersebut mungkin disebabkan oleh eksploitasi ikan tongkol komo dan tongkol abu-abu terjadi bersamaan pada armada pukat cincin dan jaring insang di Laut Jawa.

\section{KESIMPULAN}

Hubungan panjang-bobot ikan tongkol abu-abu (Thunnus tonggol) di Laut Jawa menunjukkan pertumbuhan isometrik, dengan indek pertumbuhan tergolong cepat yaitu 3,46/tahun. Panjang asimtotik $\left(\mathrm{L}_{\infty}\right)$ sebesar $85 \mathrm{~cm}$ tercapai pada umur sekitar 15 tahun. Pendugaan kecepatan pertumbuhan (K) sebesar 0,4/ tahun. Mortalitas total (Z) sebesar 1,62/tahun, mortalitas alami (M) dan mortalitas penangkapan (F) masing-masing sebesar 0,61/tahun dan 1,01/tahun. Tingkat eksploitasi (E) ikan tongkol abu-abu diduga sebesar 0,59. Hal ini menunjukkan tingkat pemanfaatan di Laut Jawa telah mencapai fully exploited.

\section{PERSANTUNAN}

Tulisan ini merupakan bagian dari kegiatan pemutakhiran data hasil tangkapan, upaya penangkapan dan ukuran ikan di WPP Laut Republik Indonesia pada Balai Riset Perikanan Laut Tahun Anggaran 2014. 
Terimakasih penulis sampaikan kepada Bapak Drs. Suwarso, M.Si atas saran dan masukannya dalam penulisan karya ilmiah ini.

\section{DAFTAR PUSTAKA}

Abdussamad, E. M., Koya, K. P. S., Ghosh, S., Rohit, P., Joshi, K. K., Manojkumar, B., Prakasan, D., Kemparaju, S., Elayath, M. N. K., Dhokia, H. K. \& Bineesh, K. K. (2012). Fishery, biology and population characteristics of longtail tuna, Thunnus tonggol (Bleeker, 1851) caught along the Indian cost. Indian J.Fish. 59 (2), 716.

Al-Siyabi, B., Al-kharusi, L., Nishida, T., \& Al-Busaidi, H. (2014). Standarization of longtail tuna (Thunnus tonggol). Catch rates of drift gillnet fisheries in Sultanate of Oman. IOTC Working Party on Tropical, 4-28.

Anonimus. (2015). Statistik Perikanan Tangkap di Laut Menurut Wilayah Pengelolaan Perikanan Laut Negara Republik Indonesia (WPP-NRI) 2005-2014. Kementerian Kelautan Perikanan Tangkap, Direktorat Jenderal Perikanan Tangkap, 2015.

Bal, D. V. \& Rao, K. V. (1984). Marine Fisheries (p. 491). New Delhi: Tata McGraw-Hill Publishing Company.

Basir, S. \& Bakar, N. A. (2011). Analysis of catch of neritic tuna and sharks in Malacca Strait, west coast of Malaysia Peninsula. IOTC Working Party on Tropical, $1-9$.

Carpenter, K. E. \& Niem, V. H. (2001). The living marine resources of the Western Central Pacific. FAO Identification Guide for Fishery Purposes, Vol. 6.

Chiang,W.C., Hsu, H. H., Fu, S. C., Chen, S. C., Sun, C. L., Chen, W. Y., Liu, D. C. \& Su, W. C. (2011). Reproductive biology of longtail tuna (Thunnus tonggol) from coastal waters of Taiwan. IOTC Working Party on Tropical, 1-30.

Chodrijah, U., Hidayat, T. \& Noegroho, T. (2013). Estimasi parameter populasi ikan tongkol komo (Euthynnus affinis) di perairan Laut Jawa. BAWAL, 5(3). 167-174.doi: http://dx.doi.org/10.15578/bawal.5.3.2013.167-174.

Collette, B. B. \& Nauen, C. E. (1983). FAO species catalogue. Vol. 2. Scombrids of the world. An annotated and illustrated catalogue of tunas, mackerels, bonitos and related species known to date (p. 137). FAO Fish Synopsis. 125(2). Rome, Italy: FAO Press
Darvishi, M., Kaymaram, F., Talebzadeh, S. A. \& Behzadi, S. (2003). Population dynamics of five Scombrid fish in Hormozgan Province Iran (p. 183). Persian Gulf and Oman Sea Ecological Research Institute (In Persian).

Froese, R. \& Pauly, D. E. (2010). Fish Base. World Wide Web electronic publication. Available at: www.fishbase.org, version (02/2010).

Griffith, S. P., Fry, G. C., Manson, F. J. \& Pillans, R. D. (2009). Feeding dynamics, consumption rates and daily ratio of longtail tuna (Thunnus tonggol) in Australian waters, with emphasis on the consumption of comercially important prawns. Marine and Freshwater Research, 58 (4), 376-397.

Griffiths, S. P., Pepperell, J., Tonks, M., Sawynok, W., Olyott, L., Tickell, S., Zischke, M. \& Moyle, K. (2010). Biology,fisheries, and status of longtail tuna (Thunnustonggol), with special reference to recreational fisheriesin Australian waters. Final Report. Fisheries Research and Development Corporation and CSIRO Marine and Atmospheric Research.

Griffiths, S. P., Fry, G. C., Manson, F. J. \& Lou, D. C. (2010). Age and growth of longtail tuna (Thunnus tonggol) in tropical and temperate waters of the central IndoPacific. ICES Journal of Marine Science, 67, 125-134.

Gulland, J. A. (1983). Fish Stock Assessment. A manual of basic methods (p. 233). John Wiley \& Sons. Chicester.

Itoh, T., Tsuji, S. \& Chow, S. (1996). Catch information of longtail tuna, Thunnus tonggol, in Japan. Proceedings of the sixth Expert Consultation on Indian Ocean Tunas, Colombo, Sri Lanka, 312-315.

Itoh, T., Yuki, Y. \& Tsuji, S. (1999). Spawning possibility and growth of longtail tuna, Thunnus tonggol, in the water around Japan. Bulletin of the National Research Institute of Far Seas Fisheries, 36, 47-53.

James, P. S. B. R., Pillai, P. P., Pillai, N. G. K., Jayaprakash, A. A., Gopakumar, G., Kasim, H. M., Sivadas, M. \& Koya, K. P. S. (1993). Fishery, biology and stock assessment of small tunas. In: Sudarsan, D. \& John, M. E. (Eds.), Tuna researchin India. Fishery survey of India, Bombay, 123-148.

Kaymaram, F., Darvishi, M., Parafkandeh, F., Ghasemi, S. \& Talebzadeh, S. A. (2011). Population dynamic parameters of Thunnus tonggol in the north of the Persian Gulf and Oman Sea. IOTC Working Party on Tropical: 01-18. 
Kaymaran, F. \& Darvishi, M. (2012). Growth and mortality parameters of Euthynnus affinis in the northern part of the Persian Gulf and Oman Sea.Second Working Party on Neritic Tunas, Malaysia, IOTC Working Party on Tropical: 02-14.

Kaymaram, F., Darvishi, M., Behzadi, S. \& Ghasemi, S. (2013). Population dynamic parameters of Thunnus tonggol (Bleeker, 1851) in the Persian Gulf and Oman. Iranian Journal of Fisheries Sciences 12(4), 855-863.

Khorshidian, K. \& Carrara, G. (1993). An analysis of length frequency of Thunnus tonggol in Hormuzgan waters. Islamiqe republique of Iran. Expert consultation on Indian Ocean tunas, TWS/93/2/4. p 12.

Nikolskii, G. V. (1969). Fish Population Dynamics (p. 323). Oliver and Boyd, Edinburg.

Nurhakim, S., Nikijuluw, V. P. H., Nugroho, D. \& Prisantoso, B. I. (2007). Fisheries management area - fisheries status by management area. Research center for capture fisheries, Jakarta. 47 p.

Pauly, D. (1980). On the interelationships between naturalmortality, growth parameters, and mean environmentaltemperature in 175 fish stocks. J. Cons. CIEM, 39(3),175-192.

Pauly. D. \& Munro, J. L. (1984). Once more on the comparison of growth in fish and invertebrates. ICLARM Fishbyte, 2(1), 21.

Pauly, D., Ingles, J. \& Neal, R. (1984). Application to shrimp stocks of objective methods for the estimation of growth, mortality, and recruitment related parameters from length frequency data (ELEFAN I and II). In penaeid shrimp-their biology \& management. Fishing news (books). Farnham-Surrey-England, 220-234.

Prabhakar, A. \& Dudley, R. G. (1989). Age, growth and mortality rates of longtail tuna in Omani waters. IndoPacific tuna development and management programme. IPTP/89/GEN/ 16,90-96.

Silas, E. G., Pillai, P. P., Srinath, M., Jayaprakash, A. A., Muthiah, C., Balan, V., Yohannan, T. M., Siraimeetan, P., Mohan, M., Livingston, P., Kunhikoya, K. K., Ayyappan, M., Sadasiva P. S. (1985). Population dynamics of tunas: Stock assessment. In: Silas, E. G. (Ed.), Tuna fisheries ofthe exclusive economic zone of India: biology and stockassessment. Bull. Cent. Mar. Fish. Res. Inst., Cochin, 36, 20-27.

Sparre, P. \& Venema, S. C. (1999). Introduksi pengkajian stok ikan tropis. Badan Penelitian dan
Pengembangan Perikanan. Terjemahan dari Introduction to tropical fish stock assessment Part 1 (p. 376). FAO Fish Tech. Paper 306(1).

Steel, R. G. D. \& Torrie, H. (1993). Prinsip dan Prosedur Statistika Suatu Pendekatan Biometrik (p. 333). Diterjemahkan oleh Bambang Sumantri. Edisi Kedua. Jakarta:PT. Gramedia Pustaka Utama.

Suman, A. \& Boer, M. (2005). Ukuran pertama kali matang kelamin, musim pemijahan, dan parameter pertumbuhan udang dogol (Metapenaeus ensis de Haan) di perairan Cilacap dan sekitarnya. Jurnal Penelitian Perikanan Indonesia. 11 (2), 69-74. doi: http://dx.doi.org/10.15578/ jppi.11.2.2005.69-74.

Supongpan, S. \& Saikliang, P. (1987). Fisheries status of tuna purse seiners (using sonar) in the Gulf of Thailand. Rep. Mar.Fish. Div. Dep. Fish., 3, p. 78.

Suwarso \& Hartati, T. (2002). Identifikasi kohor dan dugaan laju pertumbuhan ikan pelagis kecil di Laut Jawa. Jurnal Penelitian Perikanan Indonesia. 8 (4), 7 -14. doi: http://dx.doi.org/10.15578/jppi.8.4.2002.7-14.

Wagiyo, K. \& Febrianti, E. (2015). Aspek biologi dan parameter populasi ikan tongkol abu-abu (Thunnus tonggol) di peraiaran Langsa dan sekitarnya. Bawal. 7(2), 59-66. doi: http://dx.doi.org/10.15578/ bawal.7.2.2015.59-66.

Widodo, J. (1988). Dynamic pool analysis of round scads (Decapterus macrosoma) fishery in the Java Sea. $J$. Mar. Fish, 47(2), 39-58.

Wilson, M. A. (1981a). Some aspects of the biology and reproduction of longtail tuna in Oceania. In: Grant, C. J. and Walter, D. G. (Eds.), Northern pelagic fish seminar, Aust.Gov. Publ. Serv, 24-44.

Wilson, M. A. (1981b). The biology, ecology and exploitation of longtail tuna, Thunnus tonggol (Bleeker) in Oceania (p. 195). M.Sc.Thesis. School of Biological Sciences, Macquarie University, Sydney.

Yesaki, M. (1989). Estimates of age and growth of kawakawa (Euthynnus affinis), longtail tuna (Thunnus tonggol) and frigate tuna (Auxis thazard) from the Gulf of Thailand based on length data. Indo-Pacific tuna development and management programme, IPTP/89/GEN/ 17: 94-108.

Yesaki, M. (1994). A review of the biology and fisheries of the longtail tuna (Thunnus tonggol) in the Indo-Pacific region. FAO Fisheries Technical Paper, 336: 370-387. 